\title{
Kabul City Groundwater and Need for Artificial Recharge
}

\author{
Khwaja Mohammad Ashraf Noori ${ }^{1}$, Mohammad Nasim Nasimi ${ }^{2}$ \\ ${ }^{1}$ Department of Civil Engineering, Eskisehir Technical University \\ 2 Eylul Kampus, 26555 Tepebasi, Eskisehir, Turkey \\ kma_noori@eskisehir.edu.tr \\ ${ }^{2}$ Faculty of Environmental \& Water Resources Engineering, Kabul Polytechnic University \\ Kart-i-Mamorine, Kabul, Afghanistan \\ mnnasimi@kpu.edu.af
}

\begin{abstract}
The subject of this paper is the study of Kabul groundwater and need for artificial recharge. According to studies, water depth in Kabul city had significant decrease since 1963. As per observations done by AGS (Afghanistan Geological Survey) in cooperation with USGS (United States Geological Survey), groundwater level in central Kabul sub basin decreased up to 25 meters, which by continuation of this trend, Kabul city will face water shortages in the next few years. This study investigates the reason of lowering the ground water table and finding the appropriate methods for groundwater artificial recharge. In part of this study, amount of annual rainwater of Kabul city is calculated and compared with annual required water for Kabul city inhabitants. It was found that reasons for lowering groundwater levels are illegal drilling of deep wells, excessive use of groundwater to meet the needs of drinking, industrial, irrigation and agriculture purposes. Another major reason for reducing the amount of groundwater is a significant reduction in recharge process due to urbanization and reduction in rainfall amount. The immediate solution for the concerns of groundwater reduction is recharging the aquifer through rooftop rainwater. The findings of this study show that the the amount of water consumed in Kabul city is much higher than the amount of recharge water, and there is a serious need for the management of groundwater in Kabul to prevent future water losses.
\end{abstract}

Keywords: Groundwater reduction, Kabul basin, Artificial recharge, Rooftop rainwater harvesting.

\section{Introduction}

Water is the human and earth purifier and is the most important GOD given gift. However, 71 percent of the earth's surface is water-covered, but only 2.8 percent is drinkable water. When rainfall occurs, some of it flows into the rivers and eventually continues to sea, while some of it evaporates and enters again hydrological circulations and only six percent of this amount infiltrates into the earth and forms underground waterbeds. Undoubtedly, groundwater resources are available wherever rainfall occurs. Groundwater is in fact part of the surface water that naturally flows through the springs to the ground or extracted from wells and so forth from underground water. These waters are an important source of drinkable water which usually do not require any special filtration [1].

Afghanistan is surrounded by mountains which serves as a natural water storage, but due to political instability and some long-lasting wars, water supply system of country has been partially ruined. Potential water resources of Afghanistan are estimated 75 billion cubic meters from which 57 billion cubic meter is surface water and rest 18 billion cubic meter is groundwater. About 15 percent of the total water volume used annually originates from alluvial groundwater aquifers and almost $85 \%$ from rivers and streams [2]. Increasing population growth along with excessive water use have created a lot of problems in water supply of Kabul city. Approximately 20-27 percent of Kabul residents have access to the central water supply system and rest of the residents use drinking water from uncertified sources like shallow wells and hand-pumps which are mainly from groundwater [3]. According to estimates, Kabul city groundwater could meet the needs of nearly two million inhabitants, but now it's seen that the population based on this available resource has increased by about 4,635,000 in 2015, the living standards of people have risen and due to management problems, excessive amount of water has been wasted [4]. As per a study, water demand of Kabul city is about more than 120 million $\mathrm{m}^{3} /$ year with estimated population of 4,635,000 inhabitants [5]. Due to irregular and unpredictable rainfall, Kabul city faces shortage of surface and groundwater. Since the Kabul river has approximately 3 months flowing water in a year, and is completely polluted, which greatly contributes in destruction of Kabul city environment and, on the other hand, it causes groundwater pollution in the time of water flood, 
therefore, groundwater as a source plays key role in the development of the community [3]. Currently in Kabul water basin due to too much groundwater usage, high evaporation and low water recharge, reduction in underground natural reservoirs occurred, which makes anxiety in daily required amount of water for Kabul city residents now and in future [4].

Kabul basin is consisted of fan alluvium, conglomerate, loess loam, sandstones and gravel which have a good filtration capacity. Roadside ditches, sewage, leaking septic tanks and lack of public awareness of the quality and maintenance of water are sources of pollution. Another main cause of groundwater pollution is use of fertilizer for agriculture [5]. Fig 1 shows generalized schematic diagram of Kabul basin [6].

Water vulnerability will be irreparable and Kabul city will witness lack of drinking water and higher contamination. The results of research and studies show that if this procedure continues, the amount and quality of groundwater in the Kabul water basin will be irreversible [1]. Managing groundwater in Kabul city is an important issue which needs serious attention of relevant organizations to save Kabul from future water famine. Current study covers groundwater status of Kabul city using different reports, references and data, and provides solutions accordingly.



Fig. 1: Generalized hydrogeologic cross section of the Kabul Basin [6].

\section{Methodology}

\subsection{Kabul basin}

Kabul city with1,023 $\mathrm{km}^{2}$ area and 1,791 $\mathrm{m}$ above sea level in a narrow valley, wedged between the Hindu Kush mountains along the Kabul River, is the capital and largest city of Afghanistan and located in the eastern section of the country [1].

The Kabul River is a 700-kilometre-long river that emerges in Maidan Wardak province in the Sanglakh range of the Hindu Kush mountains in Afghanistan and is separated from the watershed of the Helmand river by the Unai pass and finally empties into the Indus River near Attock, Pakistan. Total catchment area of Kabul river is 76,908 square kilometres which is consisted of eight watersheds of Kabul (Including Paghman), Chak and Logar, Gorband and Panjshir, Alinegar, Konar, Shemal, Gomal and Lora. Kabul basin is located between eastern longitude of $68^{\circ} 59^{\prime} 30.9^{\prime}$ ' and $69^{\circ} 22^{\prime} 27^{\prime \prime}$ and northern latitude of $34^{\circ} 24^{\prime} 1.8^{\prime \prime}$ and $34^{\circ} 36^{\prime} 33.1^{\prime \prime}$ [7]. 
Generally, the Kabul basin is related to the Endos basin having total annual flow of 22 million cubic meters which joins the Sind river and eventually the Indian Ocean [1]. The climate in Kabul is almost semi-arid with the average annual temperature of $11.4{ }^{\circ} \mathrm{C}$. According of Ministry of Energy and Water, during winter seasons of years $2009-2015$, a temperature increases of 1.7 to $2.2^{\circ} \mathrm{C}$ has been occurred in comparison to 1960 - 1983 years, and in spring seasons this increasement has been reported between $0.3{ }^{\circ} \mathrm{C}$ to $0.9^{\circ} \mathrm{C}$ [8]. According to DACAAR (Danish Committee for Aid to Afghan Refugees) report, average annual rainfall of Kabul city during 1957 - 1977 is recorded $330 \mathrm{~mm}$ while during 2005 - 2006 it is recorded as $304.9 \mathrm{~mm}$ [3]. As per data from Ministry of Energy and Water, average annual rainfall of Kabul city from different meteorological stations during 2008 - 2013 had significant decrease $(289.68 \mathrm{~mm})$ [1] and recent average annual rainfall of Kabul city during 2006 - 2016 is reported $327.6 \mathrm{~mm}$ by Ministry of Agriculture, Irrigation and Livestock [9].

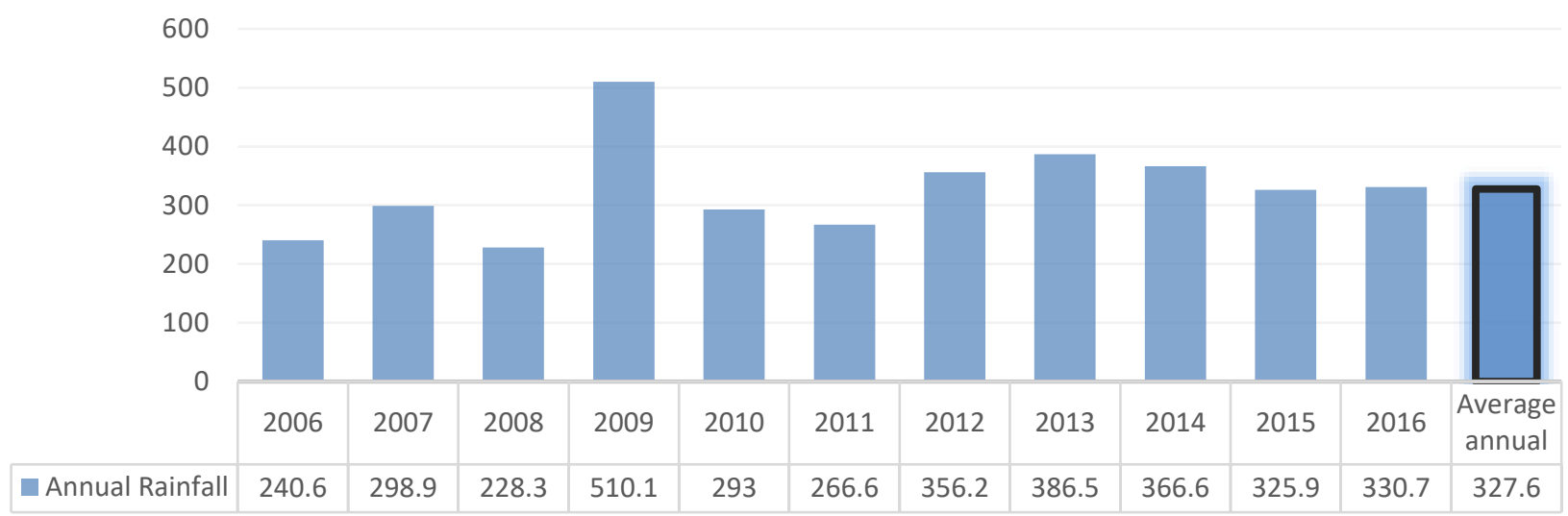

Fig. 2: Annual rainfall of Kabul city during 2006 - 2016 [9].

\subsection{Kabul city groundwater}

Due to lack of sustainable management, coordination and keeping data, little has been known about groundwater resources in Afghanistan. The groundwater resources in Kabul city was estimated to be approximately $44 \mathrm{million} \mathrm{m}^{3} / \mathrm{year}^{\mathrm{in}}$ 2015 [5]. The amount of groundwater in Kabul basin is different in different locations which is stated in Table 1, and water supply system locations are shown in Fig 3 [7]:

Table 1: Groundwater amount in Kabul basin [7].

\begin{tabular}{|l|c|c|c|c|c|c|c|c|c|c|c|}
\hline $\begin{array}{l}\text { Name of water } \\
\text { supply system }\end{array}$ & Logar & Nasaji & $\begin{array}{c}\text { Allau } \\
\text { din }\end{array}$ & $\begin{array}{c}\text { Kabul } \\
\text { Uni }\end{array}$ & Afshar & $\begin{array}{c}\text { Khair } \\
\text { khana }\end{array}$ & $\begin{array}{c}\text { Kargha } \\
\text { Koshar }\end{array}$ & Pol artal & $\begin{array}{c}\text { Wazir } \\
\text { abad }\end{array}$ & $\begin{array}{c}\text { Para } \\
\text { wan }\end{array}$ & $\begin{array}{c}\text { Micro } \\
\text { rayan }\end{array}$ \\
\hline $\begin{array}{l}\text { Managing } \\
\text { Office }\end{array}$ & $\begin{array}{c}\text { Logar, Zone1 } \\
\text { KWSS* }\end{array}$ & \multicolumn{2}{|c|}{$\begin{array}{c}\text { Zone } 4 \\
\text { KWSS }\end{array}$} & \multicolumn{2}{|c|}{$\begin{array}{c}\text { Afshar, Zone 5 } \\
\text { KWSS }\end{array}$} & $\begin{array}{c}\text { Zone 2 } \\
\text { KWSS }\end{array}$ & $\begin{array}{c}\text { Zone 3 } \\
\text { KWSS }\end{array}$ & \multicolumn{2}{|c|}{$\begin{array}{l}\text { Zone 6 } \\
\text { KWSS }\end{array}$} & $\begin{array}{c}\text { PAO, } \\
\text { MUD* }\end{array}$ \\
\hline Number of wells & 10 & 2 & 6 & 2 & 8 & 6 & $\begin{array}{c}\text { Spring1 } \\
\text { +well2 }\end{array}$ & $\begin{array}{c}1+ \\
1(\text { OOS*) }\end{array}$ & 3 & 1 & 11 \\
\hline $\begin{array}{l}\text { Number of } \\
\text { pump stations }\end{array}$ & 1 & 1 & 1 & 0 & 0 & 0 & 0 & $\begin{array}{c}1 \\
\left(\text { BPS }^{*}\right)\end{array}$ & 0 & 0 & 0 \\
\hline $\begin{array}{l}\text { Amount of } \\
\text { reservoir } \mathrm{m}^{3}\end{array}$ & 5,000 & 1,200 & 7,500 & 1,000 & $\begin{array}{c}10,000 \\
+5000\end{array}$ & 500 & 1,200 & 1,200 & 180 & 180 & 3,000 \\
\hline $\begin{array}{l}\text { Estimated lifted } \\
\text { water } \mathrm{m}^{3} / \mathrm{day}\end{array}$ & 12,000 & 2,600 & 6,700 & 6,000 & 13,500 & 3,800 & $\begin{array}{c}10,000 \\
+40\end{array}$ & 1,400 & 1,000 & 300 & 11,300 \\
\hline
\end{tabular}

* PAO : Protection of Area Office Microrayan

* MUD : Ministry of Urban Development

* BPS : Booster

* KWSS : Kabul Water Supply and Sanitation

* OOS : Out Of Service 


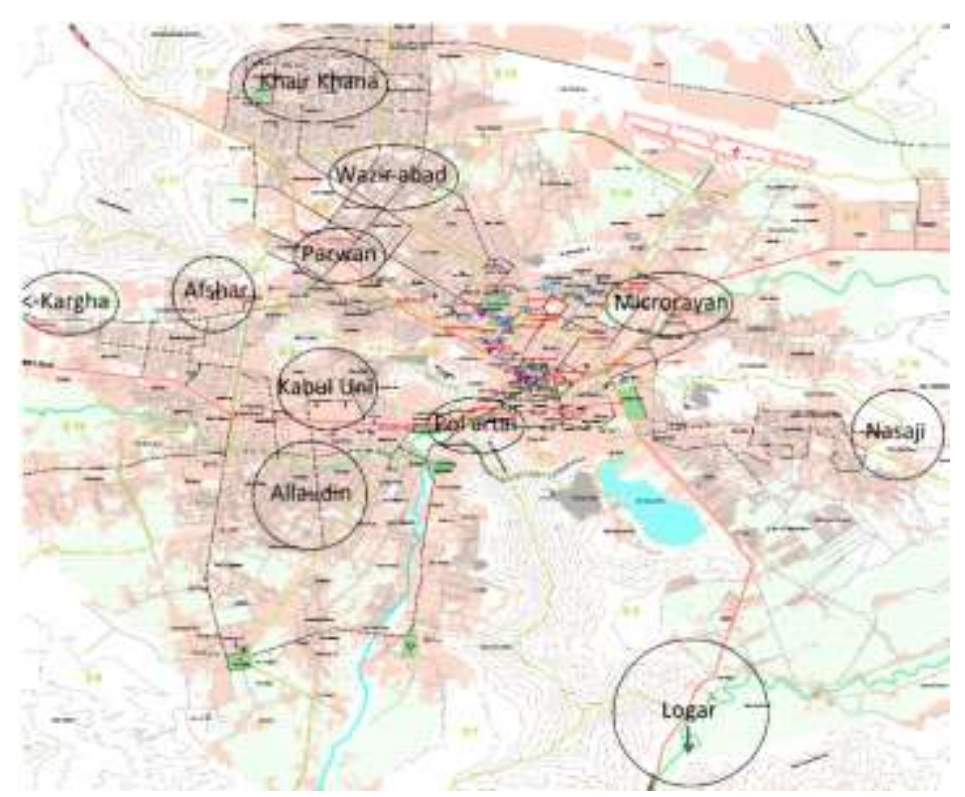

Fig. 3: Water supply system locations in Kabul city [7].

Groundwater level in the country from 1982 to 2006 felt a minimum of one meter, a maximum of 10 meters and an average of five meters down [4]. The AGS and USGS monitored groundwater level in Kabul basin during 2004 - 2013 in 71 wells. Wells are distributed in six sub basins which are Deh sabz, Logar, Central Kabul, Shomali, Panjshir, and Paghman and upper Kabul. As a result of the observations, water depths range from a minimum of $1.47 \mathrm{~m}$ in Shomali sub basin while in the Central Kabul sub basin it ranges to a maximum of 73.34 meters. Observations show that minimum depth difference is in Logar sub basin $(1.5$ - 12.4) $\mathrm{m}$ while maximum depth difference is in Central Kabul sub basin (2.64 - 73.34) m. Hydrographs for Central Kabul sub basin show decrease of water level up to 25 meters which is a warning alarm, while water level of other sub basins have less changes [10]. As per studies, a total of 61,000 hectares land with 450 million $\mathrm{m}^{3} /$ year water demand, is irrigated using groundwater resources in Kabul city [11]. Illegal drilling of deep wells, excessive use of groundwater and insufficient recharge are the main reasons of decreasing groundwater level. Groundwater concerns in Kabul city can be summed up as [1]:

- Shortage or lack of basic meteorological, hydrological and hydrogeological data required for setting up groundwater development plan.

- Shortage of technical and laboratory equipment for implementing researches.

- Weak observational and monitoring system regarding metrological, hydrological and hydrogeological data.

- Lack of rules and procedures for deep wells drilling.

\subsection{Artificial recharge}

Artificial recharge is amplifying groundwater amount through infiltration of surface water into the underground aquifers [1] and is implemented in three phases of feasibility, test program design and operation, and full-scale project implementation [12]. Besides, basic studies required for artificial recharge are [1]:

- Meteorological studies: These studies are carried out to determine the amount of rainfall, evaporative waste, and climatic characteristics.

- Hydrological studies: These studies are carried out to identify sources for artificial recharge,

- Hydrogeological studies: These studies are carried out to determine aquifer characteristics, groundwater potential and chemical specifications of water in different water bearing formations.

- Soil permeability studies

Artificial recharge methods can be divided into two groups as shown in Table 2 [12]. 
Table 2: Artificial recharge methods.

\begin{tabular}{|c|c|c|}
\hline \multirow{10}{*}{ Direct Methods } & \multirow{6}{*}{ Surface Spreading Techniques } & Flooding \\
\hline & & Ditches and Furrows \\
\hline & & Recharge Basins \\
\hline & & Run-off Conservation Structures \\
\hline & & Stream-channel Modification \\
\hline & & Surface Irrigation \\
\hline & \multirow{4}{*}{ Sub-Surface Techniques } & Injection Wells \\
\hline & & Gravity-Head Recharge Wells \\
\hline & & Connector Wells \\
\hline & & Recharge pits / Recharge Shafts \\
\hline \multirow{7}{*}{ Indirect Methods } & \multirow{3}{*}{ Induced Recharge } & Pumping Wells \\
\hline & & Collector Wells \\
\hline & & Infiltration Gallery \\
\hline & \multirow{2}{*}{ Aquifer Modification } & Bore Blasting \\
\hline & & Hydro-Fracturing \\
\hline & \multirow{2}{*}{ Groundwater Conservation Structures } & Groundwater Dams / Underground Barriers \\
\hline & & Fracture-Sealing Cementation Technique \\
\hline
\end{tabular}

\section{Analysis and Results}

With consideration of groundwater situation in Kabul city, below is a comparison of annual rainwater collected from rooftop with required amount of water for Kabul city inhabitants.

Total amount of rainwater $=$ area $\times$ average annual rainfall $\times$ coefficient of evaporation $(0.8)$

Total annual rainwater $\left(\mathrm{m}^{3}\right)=$ annual rainfall $\times$ area $=0.3276 \times 1,023,000,000=335,134,800 \mathrm{~m}^{3}$

As there is not any specific data about area of buildings in Kabul city, on the other hand, constructions and population are growing rapidly, so $50 \%$ of the area of Kabul city would be considered as buildings. This way total annual rainfall is divided by 2 to find out annual rainwater of buildings.

$$
\text { Total annual rainwater }\left(\mathrm{m}^{3}\right)=\frac{335,134,800}{2}=167,567,400 \mathrm{~m}^{3}
$$

Total annual rainwater including of evaporation $=167,567,400 \times 0.8=134,053,920 \mathrm{~m}^{3}$

According to Shubair [4], water consumption for Kabul city is supposed 120 LCD, Litre/Capita/Day and as population of Kabul city is 4,635,000 so

$$
\begin{aligned}
& \text { Required water in one day }=4,635,000 \times 120=556,200,000 \text { litres }=556,200 \mathrm{~m}^{3} \\
& \qquad \text { Required water in one year }=556,200 \times 365=203,013,000 \mathrm{~m}^{3}
\end{aligned}
$$




\section{Discussion}

Since huge amount of groundwater is used for drinking and irrigation purposes, this study only compared rainwater required water of Kabul city inhabitants. It is deduced from the above calculations and previous studies that the continuation the current situation will lead to a further lowering of groundwater level, so the solution to this is grey water reclamation artificial recharge of groundwater. Besides, surface water resources should be used along with groundwater. On the other transportation engineers in the design and construction of roads are usually trying to dispose collected rain water in the area without using, while this water can be used for irrigating green areas along the road and save water and millions of Afghanis annually. In these situations, it is suggested that roadside gutters should be designed in such a way to not prevent absorption ability on the ground.

Groundwater level descents cause a gap in underground stones which will cause enormous social and economic losses. Therefore, the Kabul underground water needs to be properly managed. Water permeable surfaces should be detected, and level, quality and effects of groundwater should be evaluated regularly. Mostly it is believed that solving the problems of groundwater is an artificial recharge, but fundamental solution is recharge and well management of aquifer. Fig 4 shows sample rooftop rainwater harvesting in tanks for groundwater recharge and daily use.

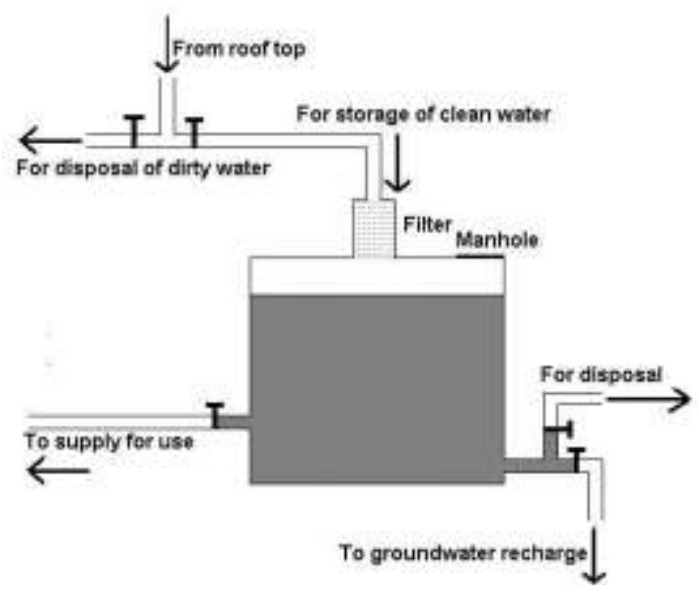

Fig. 4: Rainwater harvesting in tanks.

\section{Conclusion}

The issue of recharge in other countries is very common but has not been addressed in Afghanistan so far, only DACAAR has done some research in this regard. Since artificial recharge has a variety of species that can be selected according to the appropriate field amenities, the most suitable and most efficient way is to use appropriate recharge method using rainwater harvesting tanks to recharge groundwater. The amount of annual rainwater from the roofs and the amount of water used per capita are compared above, thus, it is concluded that if artificial recharge is not carried out in Kabul, there will be shortage of water soon in Kabul city. It should be noted that the artificial recharge cannot be summarized in this study, but for more precision and practical implementation of the artificial recharge plan, researches are needed in different areas of Kabul, so, depending on the specific characteristics of the study area, the appropriate type of recharge could be suggested. The main point to note is that recharge cannot be summed up only with the construction of the recharge water tanks, injection wells and other proposed species, but groundwater management is an important part of recharge. Without a proper management plan, it is not possible to feed satisfactory results.

\section{References}

[1] K. M. A. Noori, "Artificial recharge of ground water in Kabul City by rain water of roofs," MSc. dissertation, Dept. Hydraulic structures Eng., Kabul Polytechnic Univ., Kabul, Afghanistan, 2015. 
[2] M. H. Saffi and A. J. Kohistani, Water Resources Potential, Quality Problems, Challenges and Solutions in Afghanistan. Kabul, Afghanistan: DACAAR, 2013.

[3] M. H. Saffi, Groundwater natural resources and quality concern in Kabul Basin, Afghanistan. Kabul, Afghanistan: DACAAR, 2011.

[4] S. S. Shubair, "Kabul city ground water depletion and proposed methods of recharge," in Proceedings of the KPU National Conference on methods of developing and recharging groundwater in Kabul city and preventing contamination, Kabul, AFG, 2013, pp. 1-10.

[5] A. Zaryab., A. R. Noori., K. Wegerich and B. Klove, "Assessment of water quality and quantity trends in Kabul aquifers with an outline for future drinking water supplies," Central Asian Journal of Water Research., vol. 3, no. 2, pp. 3-11, 2017.

[6] T. J. Mack., M. A. Akbari., M. H. Ashoor., M. P. Chornack., T. B. Coplen., D. G. Emerson., B. E. Hubbard., D. W. Litke., R. L. Michel., L. N. Plummer., M. T. Rezai., G. B. Senay., J. P. Verdin and I. M. Verstraeten. (2010). Conceptual model of water resources in the Kabul Basin, Afghanistan: U.S. Geological Survey Scientific Investigations Report 2009-5262, pp. 240 [Online]. Available: http://pubs.usgs.gov/sir/2009/5262

[7] Ministry of Mines, Final report of the potential of Kabul basin groundwater resources. Kabul, Afghanistan: JICA, 2011.

[8] J. N. Shokoori. (2016). Analysis and Evaluation of Climate Change in the Kabul marine basin [Online]. Available: http://mew.gov.af/fa/news/60599

[9] O. Rahimi and K. Murakami, "Analysis of Rooftop Rainwater Harvesting in Kabul New City: A Case Study for Family Houses and Educational Facilities," Open Journal of Civil Engineering., vol. 8, pp.155-165, 2018.

[10] M. R. Taher., M. P. Chornack and T. J. Mack, Groundwater levels in the Kabul Basin, Afghanistan, 2004-2013: U.S. Geological Survey Open-File Report 2013-1296, pp. 51 [Online]. Available: http://dx.doi.org/10.3133/ofr20131296

[11] W. U. Vincent, Afghanistan: An Overview of Groundwater Resources and Challenges, Washington Crossing, USA: Uhl, Baron, Rana Associates, 2003

[12] A. K. Bhattacharya, "Artificial Ground Water Recharge with a Special Reference to India," IJRRAS., vol. 4, no. 2, pp. 214-221, 2010. 